Integritas 4.1 (Fall 2014), pp. 17-20.

doi: $10.6017 /$ integritas.v4i1p17

\title{
Response to William Werpehowski
}

\section{Aurelie A. Hagstrom}

Bill's paper makes an important contribution to our two-year conversation about Catholic higher education and mission. He poses the basic question about Catholic mission and nonviolence. He asks if Catholic colleges and universities could become "schools of nonviolence." He then advocates nonviolence as part of the core vision and practice of Catholic higher education.

Bill's paper offers us a great service by surveying the developing "Catholic peace theologies" of the twentieth century and how they led to a kind of "nonviolence movement." Indeed, it is striking that during what many have called "the bloodiest century of human history," the twentieth century, there was this alternative movement of peace and nonviolence. In his survey of Catholic social teaching, he highlights the influence of John Howard Yoder, the U.S. Catholic bishops, Dorothy Day, Daniel Berrigan, Thomas Merton, John Dear, and the papal magisterium of Pope St. John Paul II and Pope Benedict XVI. From all of these sources, Bill tells the story of the growth of a spirituality of nonviolent Christian discipleship.

After laying the foundations of an understanding of peace, nonviolence, and Christian discipleship, Bill suggests three resources for help in grappling with definitions of violence and nonviolence. His three resources are: Pope St. John Paul II's optimism about the growing respect for human life; distinctions among various kinds of violence (deadly, structural, and cultural); and third, the reality of war as a focal priority. Using these resources as a backdrop, he gives a close reading of Stephen Pope's I997 Commonweal article which puts John Henry Newman and Jon Sobrino into dialogue about the purpose of a Catholic university. In doing so, Bill invites us to imagine study and learning as activities of nonviolent attention and conceiving of a school that gives

Aurelie A. Hagstrom is an associate professor in the Department of Theology at Providence College. Dr. Hagstrom's work in ecclesiology focuses on the vocation, mission, and spirituality of the laity according to the Second Vatican Council. She is interested in how the laity are the Church in the heart of the world and how they bring the world into the heart of the Church. Recent publications include The Emerging Laity: Vocation, Mission, and Spirituality as well as articles in Ministry \& Liturgy; Journal of Catholic Higher Education; and Assembly: A Journal of Liturgical Theology. 
learning a home as a form of peace. At this point his conversation partners become Simone Weil and Stanley Hauerwas.

Finally, the third part of the paper poses five provocative questions for the Roundtable discussion of Catholic colleges and universities as schools of nonviolence. First, is the school publicly self-conscious about the practices and virtues of nonviolence? Second, is the school vigilant about promoting these practices and virtues and preserving them from corruption? Third, how are schools affected by the institutions that can and do both foster and endanger such virtues and practices? Fourth, how does the school work against violence in its stance toward the life of culture and the world of work? And fifth, what tasks must a school undertake in relation to political life, acts of war, and preparations for war?

In response to Bill's paper, I would like to focus us on these five provocative questions. It seems to me that this third section of his paper is a very practical application of the practices and virtues of nonviolence to Catholic higher education.

If I am supposed to be the conversation starter after Bill's paper, then I would simply call our attention to his first practical question: What about the practices and virtues of nonviolence on our campuses? This move to look at the end of his paper presupposes that we all accept the theology, philosophy, and spirituality of nonviolence that he works out in the body of the paper. Now, it may be the case that we do not all agree with his understanding of nonviolence. In that case, we can debate the merits of his argument. But it seems to me that a fruitful conversation can be had by granting him his understanding of nonviolence and then debating whether it is attractive or even plausible to ask a Catholic college or university to be a "school of nonviolence."

So, what about the practices and virtues of nonviolence on our campuses? What would these entail? Here, I think, we have to address the deeper question of whether or not our schools exist simply to impart knowledge or if they are also meant to provide Christian formation. If the latter, then how does a Catholic college or university become a "school of nonviolence"?

Would it mean creating an institute for peace studies on campus? A new major or minor in the academic curriculum called "nonviolence or peace studies"? Would it mean asking the campus ministry office to add programming on the topic of nonviolence in all its forms? Would we have to add one more topic to the freshman orientation experience on nonviolence? Should the mission statement of the school be edited to include language about nonviolence? I am focusing on the questions from an institutional perspective, obviously. How would the institution look different if it were a school of formation in nonviolence?

Now let me switch to the notion of virtues of nonviolence. Bill asks: How might a Catholic college or university model and instill these virtues? And, by the way, could we try to list the virtues and practices of nonviolence in a systematic way?

Recently, Pope Francis has been talking about unity in the Church. And in so doing, it seems to me that he mentions some of the same virtues that Bill would categorize as 
aspects of nonviolence. I live and teach in Rome, and so the words and actions of Pope Francis are part of my everyday life. The Italian media covers nearly everything he does. Each day there is some sort of accounting of his morning homily and any activities he has that day. On Wednesdays, excerpts from his talk at the morning general audience are usually replayed throughout the day and summarized on the evening news.

On October 22, 20I4, at his Wednesday general audience, he was commenting on I Corinthians and Paul's usage of the Body of Christ metaphor for the Church. He went on to talk about divisions in the Body and problems that the church of Corinth was facing. He said, in part:

...In the time of Paul, the community of Corinth found great difficulty in this sense, living, as we, too, often do, the experience of division, of envy, of misunderstanding and of exclusion. All of these things are not good because, instead of building up the Church and causing her to grow as the Body of Christ, they shatter it into many pieces, they dismember it. And this happens in our time as well. Let us consider, in Christian communities, in some parishes, let us think of how much division, how much envy, how they criticize, how much misunderstanding and exclusion there is in our neighbourhoods. And what does this lead to? It dismembers us among ourselves. It is the beginning of war. War does not begin on the battlefield: war, wars begin in the heart, with misunderstanding, division, envy, with this struggle with others. The community of Corinth was like this, they excelled in this! ${ }^{\text {I }}$

The words that struck me were about wars beginning in the human heart: "War does not begin on the battlefield: war, wars begin in the heart, with misunderstanding, division, envy, with this struggle with others." These are some of the vices with which Bill ends his paper as he asks whether or not Catholic schools could be a form of peace to enable us to turn away from these vices.

What about virtues of peace? In his morning homily at Casa Santa Marta on October 24, 20I5 commenting on the Letter to the Philippians, Pope Francis addressed Saint Paul's advice about building unity in the church:

Humility, gentleness, magnanimity: these are weak things, because the humble person appears good for nothing; gentleness, meekness appear useless; generosity, being open to all, having a big heart....And then he says more: Bearing with one another through love. Bearing with one another through love, having what at heart? Preserving unity. The weaker we are with these virtues of humility, generosity, gentleness, meekness, the stronger we become as stones in this Temple. ${ }^{2}$

It seems to me that the Pope is talking about some of the virtues that Bill would

1 Pope Francis, "General Audience," October 22, 2014, at http://w2.vatican.va/content/francesco/en/ audiences/2014/documents/papa-francesco_20141022_udienza-generale.html.

2 "Pope at Santa Marta: Unity in Diversity," October 24, 2014. Summary by Vatican Radio, at www.news. va/en/news/pope-at-santa-marta-unity-in-diversity. 
consider "virtues of nonviolence." These virtues look like weakness in the eyes of the world. But they are what make us strong and build up the life of the Church. How might a Catholic college or university enlarge the minds and enlarge the hearts of their students, as Bill puts it, in regards to nonviolence?

Nonviolent peaceable practices and virtues are not exactly fashionable in the Academy, in my opinion. So, I am eager to hear how they might be fostered by Catholic schools.

In conclusion, let me quote another pope, this one newly beatified. In I965, Blessed Pope Paul VI gave a famous speech at the United Nations. What most people do not know is that the pope was never formally invited to visit the UN when he came to the States. Pope Paul just showed up and asked to be received while he was in New York. And, of course, he was. In his brief address, he talked about the reality of peace. Here is, in part, what Paul VI said to the United Nations:

In a way, We have left Our purely spiritual sphere of activity in order to know your work for peace, to which you are dedicating yourselves so earnestly, and to collaborate with you insofar as it is possible for Us, and to associate Ourself, in a certain measure, with your efforts.

We have said in Our discourse that peace is the work not only, of political wisdom; it is not a result brought about only by pacts or treaties. Rather it is necessary to favour, encourage, establish and assure peace continually with concrete and specialized organs of peace-and these you are. ${ }^{3}$

What strikes me after reading Bill's paper is his line that “...peace is the work not only, of political wisdom; it is not a result brought about only by pacts or treaties. Rather it is necessary to favour, encourage, establish and assure peace continually with concrete and specialized organs of peace...." What would it mean for a Catholic college or university to be an "organ of peace"? This brings us back to Bill's original query: Is it essentially or constitutively possible for a Catholic school to be a school of nonviolence?

3 "Address of the Holy Father Paul VI," October 4, 1965, at www.vatican.va/holy_father/paul_vi/ speeches/1965/documents/hf_p-vi_spe_19651004_sacra-famiglia-new-york_en.html. 